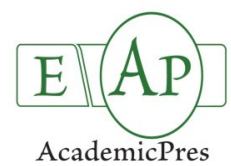

\title{
Investigation of Correlation between Traits and Path Analysis of Confectionary Sunflower Genotypes
}

\author{
Mehmet SINCIK*, A. Tanju GOKSOY \\ Uludag University, Faculty of Agriculture, Department of Field Crops, 16059, Bursa, Turkey; \\ sincik@uludag.edu.tr ("correspondingauthor); agoksoy@uludag.edu.tr
}

\begin{abstract}
This study examined the relationships between various traits associated with seeds and crude protein yields of confectionary sunflower, as well as the direct and indirect effects of these traits on crude protein yield. Eight open-pollinated confectionary sunflower populations and two open-pollinated confectionary sunflower cultivars used as control varieties were evaluated during two growing seasons. Certain agronomical and technological traits such as plant height, head diameter, seed yield, 1000-seed weight, kernel ratio, crude protein ratio and crude protein yield were measured. The results for the individual years and the combined data for both years revealed that there were significant positive correlations between the seed yield and the plant height, head diameter, 1000 -seed weight and crude protein yield. The crude protein yield was also positively and significantly correlated with the 1000-seed weight and the seed yield, but the correlations with the plant height, head diameter, kernel ratio and crude protein ratio were not significant. The path coefficients from path analysis indicated that the seed yield had the maximum positive direct effect on the crude protein yield, followed by the crude protein ratio. The greatest positive indirect effects on the crude protein yield were attributed to the 1000-seed weight, plant height and head diameter through their effects on seed yield. The magnitudes of the direct effects of the seed yield and the crude protein ratio on the crude protein yield were $79.2 \%$ and $56.9 \%$, respectively. Selection based on seed yields, 1000-seed weights and crude protein ratios could be used to improve crude protein yield in confectionary sunflower breeding programs.
\end{abstract}

Keywords: character association, crude protein yield, Helianthus annuus L., seed yield

\section{Introduction}

Two types of sunflower (Helianthus annuus L.), oilseed and confectionary sunflower, are commonly used for cultivation (Lu and Hoeft, 2009). Oilseed sunflower is the most important oilseed crop in Turkey. Recently, confectionary sunflower production has increased, mainly in the Middle and East Anatolia Region of Turkey. Thus, confectionary sunflower breeding has become more prominent over the last decade. The seeds of confectionary and oilseed sunflowers are distinguished by differences in their hullability, shell color, seed weight, morphology and kernel to pericarp weight ratio, as well as the crude protein contents (Hladni et al., 2011). Confectionary sunflower produces large seeds with low oil contents, used in baking and snack applications (Lu and Hoeft, 2009). Although the favored seed color in Turkey is white with grey stripes, consumers from Balkan countries such as Serbia, Bulgaria, Moldova and Romania prefer black seeds. The confectionary seeds preferred by Turkish individuals are usually bigger and longer, and their 1000-seed weights are higher (Kaya, 2004).

Determining the associations between traits of confectionary sunflower cultivars is an important aspect of breeding programs that aim to improve the yield and quality of confectionary sunflowers characteristics. An understanding of the relationships between yield and the factors that affect yield is a prerequisite for designing an effective breeding program (Velkov, 1980). Yield is a complex characteristic and is a function of several component characteristics and their interactions with the environment (Chikkadevaiah et al., 2002). Hence, the selection of characteristics that have a high heritability and a positive association with yield is an important requirement for improving yields through breeding programs. Many previous studies have reported that seed yields are positively correlated with the numbers of seeds per head, 1000-seed weight, head diameters and plant heights of confectionary sunflowers (Singh et al., 1985; Lal et al., 1997; Teklewold et al., 2000; Shankar et al., 2006; Kholghi et al., 2011). Hladni et al. (2009) suggested that the two most important criteria for introducing new confectionary hybrids into production are a high number of seeds per head and a high crude protein yield. The first criterion is important for farmers, while the latter is important for consumers. Hladni et al. (2011) reported a very strong positive correlation between crude protein yields and the crude protein contents of seeds, seed yields and 1000-seed weight.

Path analysis is useful for partitioning a correlation coefficient into its direct and indirect effects (Dewey and Lu, 1959). A number of studies have shown that the number of 
seeds per head can have a highly positive direct effect on seed yield (Habib et al., 2006; Shankar et al., 2006; Kholghi et al., 2011). However, Hladni et al. (2011) reported that seed yield, the crude protein content of seeds and the 1000seed weight had a large influence on the crude protein yield of confectionary sunflowers.

The aim of this study was to investigate the relationships among various characteristics of confectionary sunflowers and their seed and crude protein yields and to determine the direct and indirect effects of the examined characteristics on crude protein yields.

\section{Materials and methods}

Eight open pollinated confectionary sunflower populations (CSP-1, CSP-2, CSP-3, CSP-4, CSP-5, CSP-6, CSP-7 and CSP-8) and two open pollinated confectionary sunflower cultivars ('Çiğdem 1' and 'Ínegöl Alası') used as control varieties were sown in the experimental area of the Department of Field Crops, Faculty of Agriculture, Uludağ University, Bursa (latitude $40^{\circ} 22^{\prime} \mathrm{N}$, longitude $29^{\circ} 12^{\prime} \mathrm{E}$, altitude $155 \mathrm{~m}$ ), Turkey, in 2009 and 2010. Bursa is located in the Southern Marmara region and has a Mediterraneantype climate. The average annual rainfall is $713 \mathrm{~mm}$, and the mean monthly temperature is $14.4^{\circ} \mathrm{C}$. The soil of this site is classified as Vertisol typic habloxrert. Soil analyses revealed that the soil is a slightly alkaline $(\mathrm{pH}=7.3)$ clay loam, rich in potassium $\left(933 \mathrm{~kg} \mathrm{ha}^{-1}\right)$, with a moderate amount of phosphorus $\left(70 \mathrm{~kg} \mathrm{ha}^{-1}\right)$ and an organic matter content of $1.2 \%$.

Field experiments were conducted in a randomized, complete block design with three replications. The row-torow distance was $70 \mathrm{~cm}$, and the plant-to-plant distance was $30 \mathrm{~cm}$. Each $14 \mathrm{~m}^{2}$ plot consisted of four $5.0 \mathrm{~m}$ long rows. Sixty kilograms per hectare of both nitrogen $(\mathrm{N})$ and phosphorus $(\mathrm{P})$ were applied as a combined fertilizer (2020-0) prior to sowing. Another $60 \mathrm{~kg} \mathrm{~N}^{-1}$ were added when the plants reached their reproductive stage. Before emergence, Linuron was sprayed at a rate of $0.20 \mathrm{~mL} \mathrm{~m}^{-2}$ for weed control. Plants were irrigated three times at different growth periods: heading, flowering and milking stages. Hand hoeing was performed after each irrigation event. Plots were harvested by hand during the period of physiological maturation and then threshed to determine the seed yield and other characteristics.

The plant height $(\mathrm{cm})$, head diameter $(\mathrm{cm})$, seed yield $\left(\mathrm{kg} \mathrm{ha}^{-1}\right)$, 1000-seed weight (g), kernel ratio (\%), crude protein ratio (\%) and crude protein yield $\left(\mathrm{kg} \mathrm{ha}^{-1}\right)$ were recorded. Plant height and head diameter were measured on ten plants selected randomly from each of the plots in both years. The crude protein ratio was determined by using the Kjeldahl method. An analysis of variance was performed for each trait for each individual year and for the combined data from both years. The simple correlation coefficients among all of the studied traits were calculated according to the method given by Singh and Chaudhary (1979). Path coefficients were analyzed as described by Dewey and Lu (1959) to determine the direct and indirect effects of different agronomical and technological traits on the crude protein yields.

\section{Results}

The mean values and statistical differences of the observed traits among the ten confectionary sunflower genotypes are presented in Tab. 1. There was a significant effect of the year on the differences observed in the examined traits among the genotypes. Therefore, the two experimental years were evaluated separately. In addition, significant differences were found among the genotypes for every trait in both experimental years. The mean values of the examined genotypes revealed that the plant heights $(110.3-207.0 \mathrm{~cm})$, head diameters $(11.6-15.3 \mathrm{~cm})$, seed yields (2552.0-3410.9 $\mathrm{kg} \mathrm{ha}^{-1}$ ), 1000-seed weights (82.0$108.0 \mathrm{~g})$, kernel ratios (54.0-62.0\%), crude protein ratios (18.8-23.4\%) and crude protein yields $\left(567.4-727.6 \mathrm{~kg} \mathrm{ha}^{-1}\right.$, respectively, in 2009. However, in 2010, the ranges for the same traits were $122.7-216.3 \mathrm{~cm}, 13.8-18.5 \mathrm{~cm}, 2717.9$ $3713.3 \mathrm{~kg} \mathrm{ha}^{-1}, 104.0-125.7 \mathrm{~g}, 50.0-56.0 \%, 18.3-23.1 \%$ and $547.4-756.1 \mathrm{~kg} \mathrm{ha}^{-1}$, respectively. The results indicated that the genotypes, CSP-3, CSP-4 and CSP-5 were the most promising lines for a majority of the studied traits (Tab. 1).

The correlation coefficients between the seed yields and the plant heights $(\mathrm{r}=0.768 ; \mathrm{p}<0.01)$, head diameters $(r=0.733 ; p<0.05), 1000$-seed weights $(r=0.831 ; p<0.01)$

Tab. 1. Average values of examined traits of confectionary sunflower genotypes

\begin{tabular}{|c|c|c|c|c|c|c|c|}
\hline Genotypes & $\mathrm{PH}(\mathrm{cm})$ & $\mathrm{HD}(\mathrm{cm})$ & $\mathrm{SY}\left(\mathrm{Kg} \mathrm{ha}^{-1}\right)$ & TSW (g) & $\mathrm{KR}(\%)$ & CPR (\%) & CPY $\left(\mathrm{Kg} \mathrm{ha}^{-1}\right)$ \\
\hline \multicolumn{8}{|c|}{2009} \\
\hline CSP-1 & $195.0 \mathrm{~b}-\mathrm{d}$ & $14.6 \mathrm{ab}$ & $2910.1 \mathrm{~cd}$ & $90.0 \mathrm{~cd}$ & $58.0 \mathrm{ab}$ & $22.6 \mathrm{ab}$ & $658.1 \mathrm{ab}$ \\
\hline CSP-2 & $207.0 \mathrm{a}$ & $15.0 \mathrm{ab}$ & $2993.0 \mathrm{bc}$ & $93.0 \mathrm{~cd}$ & $54.0 \mathrm{~b}$ & $19.3 \mathrm{~cd}$ & $567.4 \mathrm{c}$ \\
\hline CSP-3 & $168.0 \mathrm{e}$ & $13.0 \mathrm{ab}$ & $3103.6 \mathrm{~b}$ & $96.0 \mathrm{bc}$ & $62.0 \mathrm{a}$ & $23.4 \mathrm{a}$ & $727.6 \mathrm{a}$ \\
\hline CSP-4 & $196.0 \mathrm{bc}$ & $12.9 \mathrm{ab}$ & $3440.3 \mathrm{a}$ & $106.0 \mathrm{a}$ & $57.0 \mathrm{ab}$ & $20.5 \mathrm{~b}-\mathrm{d}$ & $706.3 \mathrm{ab}$ \\
\hline CSP-5 & $192.0 \mathrm{~cd}$ & $14.3 \mathrm{ab}$ & $3380.7 \mathrm{a}$ & $108.0 \mathrm{a}$ & $56.0 \mathrm{ab}$ & $18.8 \mathrm{~d}$ & $635.0 \mathrm{bc}$ \\
\hline CSP-6 & $192.7 \mathrm{~cd}$ & $15.3 \mathrm{a}$ & $3420.4 \mathrm{a}$ & $104.0 \mathrm{a}$ & $54.0 \mathrm{~b}$ & 20.7 b-d & $707.3 \mathrm{ab}$ \\
\hline CSP-7 & $110.3 \mathrm{f}$ & $13.3 \mathrm{ab}$ & $2552.0 \mathrm{e}$ & $82.0 \mathrm{e}$ & $57.0 \mathrm{ab}$ & $22.4 \mathrm{ab}$ & $570.5 c$ \\
\hline CSP-8 & $201.3 \mathrm{ab}$ & $14.0 \mathrm{ab}$ & $3410.9 \mathrm{a}$ & $102.0 \mathrm{ab}$ & $56.0 \mathrm{ab}$ & $19.3 \mathrm{~cd}$ & $657.2 \mathrm{ab}$ \\
\hline Cigdem & $166.3 \mathrm{e}$ & $11.6 \mathrm{~b}$ & $2783.5 \mathrm{~d}$ & $86.0 \mathrm{de}$ & $56.3 \mathrm{ab}$ & $23.1 \mathrm{a}$ & $641.4 \mathrm{bc}$ \\
\hline İnegol & $187.0 \mathrm{~d}$ & $15.6 \mathrm{a}$ & $3360.2 \mathrm{a}$ & $103.0 \mathrm{ab}$ & $54.0 \mathrm{~b}$ & $21.3 \mathrm{a}-\mathrm{c}$ & $718.9 \mathrm{a}$ \\
\hline $\operatorname{LSD}(0.05)$ & 8.15 & 3.49 & 138.9 & 7.67 & 6.62 & 2.22 & 74.3 \\
\hline \multicolumn{8}{|c|}{2010} \\
\hline CSP-1 & $175.3 \mathrm{~d}$ & $13.9 \mathrm{~d}$ & $3010.4 \mathrm{~d}$ & $109.3 \mathrm{~cd}$ & $55.0 \mathrm{ab}$ & $19.4 \mathrm{de}$ & $582.0 \mathrm{~d}$ \\
\hline CSP-2 & $194.0 \mathrm{c}$ & $14.3 \mathrm{~d}$ & 2853.7 e & $106.3 \mathrm{~d}$ & $54.7 \mathrm{a}-\mathrm{c}$ & $19.2 \mathrm{~d}-\mathrm{f}$ & $547.4 \mathrm{~d}$ \\
\hline CSP-3 & $213.7 \mathrm{a}$ & $16.4 \mathrm{bc}$ & $3713.3 \mathrm{a}$ & $125.7 \mathrm{a}$ & $50.3 \mathrm{e}$ & $18.3 \mathrm{f}$ & $681.6 \mathrm{bc}$ \\
\hline CSP-4 & $204.7 \mathrm{~b}$ & $16.3 \mathrm{bc}$ & $3310.5 \mathrm{c}$ & $104.0 \mathrm{~d}$ & $53.3 \mathrm{bc}$ & $23.1 \mathrm{a}$ & $756.1 \mathrm{a}$ \\
\hline CSP-5 & $212.3 \mathrm{a}$ & $15.9 c$ & $3637.0 \mathrm{ab}$ & $118.3 \mathrm{~b}$ & $55.3 \mathrm{a}$ & $19.5 \mathrm{c}-\mathrm{e}$ & $708.4 \mathrm{a}-\mathrm{c}$ \\
\hline
\end{tabular}




\begin{tabular}{|c|c|c|c|c|c|c|c|}
\hline CSP-6 & $213.3 \mathrm{a}$ & $17.4 \mathrm{ab}$ & $3360.5 c$ & $106.0 \mathrm{~d}$ & $56.0 \mathrm{a}$ & $21.4 \mathrm{~b}$ & $718.3 \mathrm{ab}$ \\
\hline CSP-7 & $122.7 \mathrm{e}$ & $13.8 \mathrm{~d}$ & $2717.9 \mathrm{e}$ & $115.0 \mathrm{bc}$ & $51.3 \mathrm{de}$ & $20.4 \mathrm{bc}$ & $554.1 \mathrm{~d}$ \\
\hline CSP-8 & $194.3 \mathrm{c}$ & $18.5 \mathrm{a}$ & $3547.2 \mathrm{~b}$ & $104.3 \mathrm{~d}$ & $50.0 \mathrm{e}$ & $18.9 \mathrm{~d}-\mathrm{f}$ & $660.8 \mathrm{bc}$ \\
\hline Cigdem & $202.0 \mathrm{~b}$ & $15.7 \mathrm{c}$ & $3583.6 \mathrm{ab}$ & $119.0 \mathrm{~b}$ & $53.0 \mathrm{~cd}$ & $18.4 \mathrm{ef}$ & $662.7 \mathrm{bc}$ \\
\hline İnegol & $216.3 \mathrm{a}$ & $16.7 b c$ & $3613.8 \mathrm{ab}$ & $119.3 \mathrm{~b}$ & $55.0 \mathrm{ab}$ & $19.6 \mathrm{~cd}$ & $654.5 \mathrm{c}$ \\
\hline $\operatorname{LSD}(0.05)$ & 5.74 & 1.42 & 155.1 & 5.86 & 1.89 & 1.02 & 64.1 \\
\hline \multicolumn{8}{|c|}{ Two-year average } \\
\hline CSP-1 & $185.2 \mathrm{~d}$ & $14.2 \mathrm{~b}$ & $2960.4 \mathrm{e}$ & $99.7 \mathrm{~cd}$ & 56.5 & $20.9 \mathrm{ab}$ & $620.3 \mathrm{e}$ \\
\hline CSP-2 & $200.5 \mathrm{ab}$ & $14.6 \mathrm{ab}$ & $2923.1 \mathrm{e}$ & $99.5 \mathrm{~cd}$ & 54.3 & $19.2 \mathrm{~cd}$ & $557.5 \mathrm{f}$ \\
\hline CSP-3 & $190.8 \mathrm{c}$ & $14.7 \mathrm{ab}$ & $3408.0 \mathrm{bc}$ & $110.8 \mathrm{a}$ & 56.2 & $20.8 \mathrm{ab}$ & $704.2 \mathrm{a}-\mathrm{c}$ \\
\hline CSP-4 & $200.3 \mathrm{ab}$ & $14.6 \mathrm{ab}$ & $3375.2 \mathrm{c}$ & $105.0 \mathrm{~b}$ & 55.2 & $21.8 \mathrm{a}$ & $731.7 \mathrm{a}$ \\
\hline CSP-5 & $202.2 \mathrm{ab}$ & $15.1 \mathrm{ab}$ & $3508.7 \mathrm{a}$ & $113.2 \mathrm{a}$ & 55.7 & $19.1 \mathrm{~d}$ & $671.4 \mathrm{~b}-\mathrm{d}$ \\
\hline CSP-6 & $203.0 \mathrm{a}$ & $16.4 \mathrm{a}$ & $3390.1 \mathrm{bc}$ & $105.2 \mathrm{~b}$ & 55.0 & $21.0 \mathrm{ab}$ & $713.0 \mathrm{ab}$ \\
\hline CSP-7 & $116.5 \mathrm{e}$ & $13.5 \mathrm{~b}$ & $2633.5 \mathrm{f}$ & $98.5 \mathrm{~d}$ & 54.2 & $21.4 \mathrm{ab}$ & $562.5 \mathrm{f}$ \\
\hline CSP-8 & $197.8 \mathrm{~b}$ & $16.3 \mathrm{a}$ & $3478.2 \mathrm{ab}$ & $103.2 b c$ & 53.0 & $19.0 \mathrm{~d}$ & $659.3 \mathrm{c}-\mathrm{e}$ \\
\hline Cigdem & $184.2 \mathrm{~d}$ & $13.7 \mathrm{~b}$ & $3183.9 \mathrm{~d}$ & $102.5 \mathrm{~b}-\mathrm{d}$ & 54.7 & $20.8 \mathrm{ab}$ & $651.6 \mathrm{de}$ \\
\hline İnegol & $201.7 \mathrm{ab}$ & $16.2 \mathrm{a}$ & $3487.0 \mathrm{ab}$ & $111.2 \mathrm{a}$ & 54.5 & $20.4 b c$ & $686.1 \mathrm{a}-\mathrm{d}$ \\
\hline $\operatorname{LSD}(0.05)$ & 6.81 & 2.58 & 142.3 & 6.60 & $n s$ & 1.67 & 67.1 \\
\hline
\end{tabular}

Note: Different letters between genotypes denote significant differences (LSD test, P<0.05) PH: Plant height; HD: Head diameter; SY: Seed yield; TSW: Thousand seed weight, KR: Kernel ratio, CPR: Crude protein ratio, CPY: Crude protein yield.

and crude protein yields $(\mathrm{r}=0.852 ; \mathrm{p}<0.01)$ were positive and significant for the two-year combined data. In contrast, seeds yields were negatively and non-significantly associated with the crude protein ratios $(\mathrm{r}=-0.264 ; \mathrm{ns})$ and kernel ratios $(\mathrm{r}=-0.053$, ns). Relatively similar results were also obtained for the individual years (Tab. 2).

The correlation analyses of the combined two years of data revealed that crude protein yields were only significant and positively correlated with the 1000 -seed weights $(\mathrm{r}=$ 0.699; $\mathrm{p}<0.05)$ and seed yields $(\mathrm{r}=0.852 ; \mathrm{p}<0.01)$, but not significantly correlated with the plant heights, head diameters, kernel ratios and crude protein ratios. The correlation results for the individual years in terms of the crude protein yield were also similar to the two-year combined data. However, the significant correlation between the crude protein yields and 1000-seed weights observed in the combined data was not significant for neither individual year. The kernel ratio and the crude protein ratio had insignificant correlative associations with all of the other observed traits (Tab. 2). In addition, plant height was positively and significantly associated with head diameter $(r=0.633 ; \mathrm{p}<0.01)$.

The results of the path analysis revealed that the seed yield and the crude protein ratio had the greatest direct positive effects on the crude protein yield in both experimental years and in the combined data (Tab. 3). For the two-year combined data, the direct effect of seed yield on crude protein yield was $79.2 \%$, with a positive

Tab. 2. Correlation coefficient of the analyzed traits with crude protein yield

\begin{tabular}{|c|c|c|c|c|c|c|}
\hline Traits & HD & SY & TSW & $\mathrm{KR}$ & CPP & CPY \\
\hline \multicolumn{7}{|c|}{$\mathrm{PH}$} \\
\hline 2009 & $0.451^{\mathrm{ns}}$ & $0.716^{*}$ & $0.661^{*}$ & $-0.323^{\mathrm{ns}}$ & $-0.586^{\mathrm{ns}}$ & $0.312^{\mathrm{ns}}$ \\
\hline 2010 & $0.633^{*}$ & $0.789^{* *}$ & $0.108^{\mathrm{ns}}$ & $0.318^{\mathrm{ns}}$ & $-0.057^{\mathrm{ns}}$ & $0.684^{*}$ \\
\hline 2-yr average & $0.633^{*}$ & $0.768^{* *}$ & $0.511^{\mathrm{ns}}$ & $-0.172^{\mathrm{ns}}$ & $-0.400^{\mathrm{ns}}$ & $0.581^{\mathrm{ns}}$ \\
\hline \multicolumn{7}{|c|}{ HD } \\
\hline 2009 & & $0.415^{\mathrm{ns}}$ & $0.413^{\mathrm{ns}}$ & $-0.550^{\mathrm{ns}}$ & $-0.480^{\mathrm{ns}}$ & $0.068^{\mathrm{ns}}$ \\
\hline 2010 & & $0.747^{*}$ & $-0.124^{\mathrm{ns}}$ & $-0.196^{\mathrm{ns}}$ & $0.058^{\mathrm{ns}}$ & $0.708^{*}$ \\
\hline 2 -yr average & & $0.733^{*}$ & $0.505^{\mathrm{ns}}$ & $-0.270^{\mathrm{ns}}$ & $-0.388^{\mathrm{ns}}$ & $0.520^{\mathrm{ns}}$ \\
\hline \multicolumn{7}{|c|}{ SY } \\
\hline 2009 & & & $0.980^{* *}$ & $-0.257^{\mathrm{ns}}$ & $-0.612^{* *}$ & $0.636^{*}$ \\
\hline 2010 & & & $0.444^{\mathrm{ns}}$ & $-0.101^{\mathrm{ns}}$ & $-0.266^{\mathrm{ns}}$ & $0.730^{*}$ \\
\hline 2 -yr average & & & $0.831^{* *}$ & $-0.053^{\mathrm{ns}}$ & $-0.264^{\mathrm{ns}}$ & $0.852^{* *}$ \\
\hline \multicolumn{7}{|c|}{ TSW } \\
\hline 2009 & & & & $-0.243^{\mathrm{ns}}$ & $-0.650^{*}$ & $0.573^{\mathrm{ns}}$ \\
\hline 2010 & & & & $-0.177^{\mathrm{ns}}$ & $-0.534^{\mathrm{ns}}$ & $0.006^{\mathrm{ns}}$ \\
\hline 2-yr average & & & & $-0.284^{\mathrm{ns}}$ & $-0.202^{\mathrm{ns}}$ & $0.699^{*}$ \\
\hline \multicolumn{7}{|c|}{$\mathrm{KR}$} \\
\hline 2009 & & & & & $0.600^{\mathrm{ns}}$ & $0.260^{\mathrm{ns}}$ \\
\hline 2010 & & & & & $0.295^{\mathrm{ns}}$ & $0.086^{\mathrm{ns}}$ \\
\hline 2 -yr average & & & & & $0.318^{\mathrm{ns}}$ & $0.270^{\mathrm{ns}}$ \\
\hline \multicolumn{7}{|c|}{ CPR } \\
\hline 2009 & & & & & & $0.221^{\mathrm{ns}}$ \\
\hline 2010 & & & & & & $0.426^{\mathrm{ns}}$ \\
\hline 2-yr average & & & & & & $0.264^{\mathrm{ns}}$ \\
\hline
\end{tabular}

Note: ${ }^{*}$ significant at $\mathrm{p}=0.05$ probability level; ${ }^{* *}$ : significant at $\mathrm{p}=0.01$ probability level; $\mathrm{n}$ : not significant; PH: Plant height; HD: Head diameter; SY: Seed yield; TSW:

Thousand seed weight, KR: Kernel ratio, CPR: Crude protein ratio, CPY: Crude protein yield. 
correlation coefficient $(\mathrm{r}=0.852 ; \mathrm{p}<0.01)$. The crude protein ratio had the second greatest direct effect on crude protein yields. According to the two-year combined data, the direct effect of crude protein ratio on crude protein yield was $56.9 \%$, but the positive correlation was not significant $(r=0.264 ; n s)$. In general, the direct effect of the 1000-seed weight was negative and of a moderate level. The percentages of this negative direct effect were $18.4 \%$ and $11.7 \%$ for the 2010 and combined data, respectively. The direct effects of the other traits on crude protein yields were smaller in magnitude and inconsistent between years ( Tab. $3)$. The highest positive indirect effects on crude protein yield were obtained for the 1000-seed weight $(+0.910)$, plant height $(+0.842)$ and head diameter $(+0.803)$ through their impacts on seed yield. The 1000-seed weight, plant height and head diameter had indirect effects (through seed yield) on crude protein yield of $75.5 \%, 72.0 \%$ and $70.9 \%$, respectively. The analysis of the two-year combined data also revealed positive indirect effects of similar magnitudes. In addition, the kernel ratio exhibited a positive indirect effect on crude protein yield of 40.9-63.7\% via its impact on crude protein ratios in the both experimental years and in the combined data. The indirect effects of the other characteristics on crude protein yield were smaller in magnitude (Tab. 3).

\section{Discussion}

There was a high degree of variability among the confectionary sunflower genotypes in terms of all of the measured traits, in both experimental years (Tab. 1). In general, the mean values of most of the studied

Tab. 3. Direct and indirect effects of agronomic traits on crude protein yield

\begin{tabular}{|c|c|c|c|c|c|c|c|c|c|c|c|c|c|c|}
\hline \multirow{3}{*}{ Traits } & \multirow{3}{*}{$\begin{array}{l}\text { Direct } \\
\text { effect }\end{array}$} & \multirow{3}{*}{$\%$} & \multicolumn{12}{|c|}{ Indirect effect } \\
\hline & & & \multicolumn{2}{|c|}{$\mathrm{PH}$} & \multicolumn{2}{|c|}{ HD } & \multicolumn{2}{|c|}{ SY } & \multicolumn{2}{|c|}{ TSW } & \multicolumn{2}{|c|}{ KR } & \multicolumn{2}{|c|}{ CPR } \\
\hline & & & PC & $\%$ & PC & $\%$ & $\mathrm{PC}$ & $\%$ & $\mathrm{PC}$ & $\%$ & $\mathrm{PC}$ & $\%$ & $\mathrm{PC}$ & $\%$ \\
\hline \multicolumn{15}{|c|}{2009} \\
\hline $\mathrm{PH}$ & -0.002 & 0.11 & & & 0.016 & 1.09 & 0.865 & 58.61 & 0.013 & 0.88 & -0.001 & 0.05 & -0.579 & 39.25 \\
\hline $\mathrm{HD}$ & -0.036 & 3.51 & -0.001 & 0.07 & & & 0.500 & 49.04 & 0.008 & 0.79 & -0.001 & 0.13 & -0.474 & 46.44 \\
\hline SY & 1.207 & 65.35 & -0.001 & 0.06 & 0.015 & 0.80 & & & 0.019 & 1.04 & -0.001 & 0.03 & -0.604 & 32.69 \\
\hline TSW & 0.019 & 1.05 & -0.001 & 0.06 & 0.015 & 0.79 & 1.182 & 63.55 & & & -0.001 & 0.03 & -0.642 & 34.50 \\
\hline $\mathrm{KR}$ & 0.002 & 0.03 & 0.001 & 0.06 & -0.020 & 2.12 & -0.311 & 33.37 & -0.005 & 0.51 & & & 0.593 & 63.67 \\
\hline CPR & 0.987 & 56.15 & 0.001 & 0.05 & -0.017 & 0.98 & -0.738 & 42.00 & -0.013 & 0.73 & 0.002 & 0.08 & & \\
\hline \multicolumn{15}{|c|}{2010} \\
\hline $\mathrm{PH}$ & -0.011 & 0.90 & & & -0.160 & 13.40 & 0.939 & 78.68 & -0.023 & 1.89 & -0.023 & 1.95 & -0.038 & 3.18 \\
\hline HD & -0.252 & 20.58 & -0.007 & 0.55 & & & 0.888 & 72.42 & 0.026 & 2.11 & 0.014 & 1.17 & 0.039 & 3.16 \\
\hline SY & 1.190 & 71.49 & -0.008 & 0.51 & -0.188 & 11.33 & & & -0.093 & 5.57 & 0.007 & 0.44 & -0.177 & 10.64 \\
\hline TSW & -0.209 & 18.35 & -0.001 & 0.10 & 0.031 & 2.75 & 0.528 & 46.39 & & & 0.013 & 1.13 & -0.356 & 31.26 \\
\hline $\mathrm{KR}$ & -0.073 & 15.24 & -0.003 & 0.71 & 0.049 & 10.32 & -0.120 & 25.08 & 0.037 & 7.69 & & & 0.196 & 40.95 \\
\hline CPR & 0.666 & 58.91 & 0.001 & 0.05 & -0.015 & 1.30 & -0.316 & 27.96 & 0.112 & 9.86 & -0.022 & 1.91 & & \\
\hline \multicolumn{15}{|c|}{ Two year average } \\
\hline PH & -0.026 & 2.26 & & & 0.014 & 1.24 & 0.842 & 72.03 & -0.072 & 6.14 & 0.018 & 1.58 & -0.196 & 16.75 \\
\hline HD & 0.023 & 2.02 & -0.017 & 1.48 & & & 0.803 & 70.91 & -0.071 & 6.26 & -0.029 & 2.55 & -0.190 & 16.76 \\
\hline SY & 1.096 & 79.17 & -0.020 & 1.47 & 0.017 & 1.21 & & & -0.116 & 8.42 & 0.006 & 0.41 & -0.129 & 9.31 \\
\hline TSW & -0.140 & 11.65 & -0.013 & 1.12 & 0.012 & 0.96 & 0.910 & 75.53 & & & 0.030 & 2.52 & -0.099 & 8.21 \\
\hline $\mathrm{KR}$ & 0.107 & 28.88 & -0.004 & 1.22 & -0.006 & 1.66 & 0.058 & 15.61 & -0.039 & 10.72 & & & 0.155 & 41.89 \\
\hline CPR & 0.489 & 56.87 & 0.011 & 1.23 & -0.009 & 1.03 & -0.289 & 33.59 & 0.028 & 3.30 & 0.034 & 3.97 & & \\
\hline
\end{tabular}

Note: PH: Plant height; HD: Head diameter; SY: Seed yield; TSW: Thousand seed weight, KR: Kernel ratio, CPR: Crude protein ratio, PC: Path coefficient.

characteristics of the genotypes were higher in the second year than those recorded in the first year. These higher mean values were likely attributed to the impact of the greater amount of spring precipitation that occurred in the second year compared to the first year. The genotypes exhibited considerable differences between years in most of the observed traits because of the significant genotype $\mathrm{x}$ environment interactions.

A successful breeding program for confectionary sunflower requires knowledge of a well-defined association between agronomical and technological characteristics. In this study, the correlations between seed yield and the plant height, head diameter, 1000-seed weight and crude protein yield were positive and highly significant. Previous studies have similarly reported that the association between seed yield and the 1000-seed weight is positive and significant (Shankar et al., 2006; Hladni et al., 2010; Hladni et al., 2011; Kholghi et al., 2011). In contrast to these results, Shrinivasa (1982) and Tariq et al. (1992) reported a negative correlation between seeds yield and the 1000-seed weight. On the other hand, our findings are in agreement with those of Marinkovic (1992), Tahir et al. (2002) and Vidhyavathi et al. (2005), who reported that the association between seed yield and the head diameter is positive and significant. However, our results did not support the conclusion of Manivannan et al. (2007), who reported that the correlation between seed yield and the head diameter was negative and non-significant. This discordance among results is most likely associated with differences in the genetic material and environmental conditions used in these studies. Hladni et al. (2011) reported that the two most important criteria for introducing new confectionary hybrids into production are a high seed yield and a high crude protein yield. The same authors noted that there is a very strong positive correlation between seed yield and crude protein yield. The earlier findings of Hladni et al. (2011) conform to our results. In this study, the correlations between all of the other traits measured were generally not significant and were also inconsistent between years. This lack of significant correlations for these traits found in our 
231

study is not consistent with results of various previous studies that reported positive and significant correlations between seed crude protein content and seed yield (Hladni et al., 2010 and 2011), seed crude protein content and kernel ratio (Hladni et al., 2011), 1000-seed weight and head diameter (Marinkovic, 1992; Kholghi et al., 2011), and seed crude protein content and crude protein yield (Hladni et al., 2011).

As demonstrated by the path analysis results, seed yield had the greatest direct positive effect on crude protein yields, and crude protein ratio the second greatest direct positive effect. These results correspond to those of Hladni et al. (2011), who reported that the seed yield, seed crude protein content and 1000-seed weight all had a large influence on crude protein yield. In addition, Kholghi et al. (2011) found that the number of seeds per head, 1000-seed weight and head diameter had positive direct effects on seed yields of confectionary sunflowers.

\section{Conclusion}

The results from this study indicated that seed yield was positively and significantly correlated with plant height, head diameter, 1000-seed weight and crude protein yield. Crude protein yield was positively and significantly correlated with 1000-seed weight and seed yield, but not significantly correlated with plant height, head diameter, kernel ratio and crude protein ratio. The path analysis results revealed that seed yield, followed by crude protein ratio, had the greatest direct positive effect on crude protein yield. The greatest positive indirect effects on crude protein yield were exhibited by the 1000-seed weight, plant height and head diameter though their impacts on seed yield. Therefore, breeding programs based on selection for seed yield, 1000-seed weight and crude protein ratio may be used to improve the crude protein yield of confectionary sunflowers.

\section{Acknowledgements}

This research work was supported by The Office of Scientific Research Projects of Uludag University (Project No. 2009/17. Project Leader: Assoc. Prof. Dr. Mehmet Sincik).

\section{References}

Chikkadevaiah SHL, Nandini R (2002). Correlation and path analysis in sunflower. Helia 25(37):109-118.

Dewey DR, Lu KH (1959). A correlation and path coefficient analysis of components of crested wheat grass seed production. Agron J 51(9):515-518.

Habib H, Mehdi SS, Rashid A, Anjum MA (2006). Genetic association and path analysis for seed yield in sunflower (Helianthus annuus L.). Pak J Agri Sci 43:131-135.

Hladni N, Jocic S, Miklic V, Dušanic N, Saftic-Pankovic D, Radeka I, Lecic N (2009). The evaluation of values of new confectionery sunflower hybrids. Proc 50th Oil Industry Conf, Herceg Novi, 57-61p.
Hladni N, Jocic S, Miklic V, Mijic A, Saftic-Pankovic D, Škoric D (2010). Effect of morphological and physiological traits on seed yield and oil content in sunflower. Helia 33(53):101-115.

Hladni N, Jocic S, Miklic V, Safticpankovic D, Kraljevic-Balalic M (2011). Interdependence of yield and yield components of confectionary sunflower hybrids. Genetika 43(3):583-594.

Kaya Y (2004). Confectionery sunflower production in Turkey. Proceeding of $16^{\text {th }}$ International Sunflower Conference. August 29-September 2. Fargo, USA. 817-822.

Kholghi M, Bernousi I, Darvishzadeh R, Pirzad A, Hatami Maleki $\mathrm{H}$ (2011). Collection, evaluation and classification of Iranian confectionary sunflower (Helianthus annuus L.) populations using multivaraite statistical techniques. Afr J Biotechnol 10:5444-5451.

Lal GS, Bhaderiya VS, Singh AK (1997). Genetic association and path analysis in elite lines of sunflower. Crop Res Hisar 13(3):631-634.

Lu G, Hoeft E (2009). Sunflower, p. 125-168. In: Kole C, Hall TC (Eds.). Compendium of transgenic crop plants, vol 2. Wiley-Blackwell, London.

Manivannan N, Karthika R, Punitha B, Vindhiyavarman P, Muralidharan V (2007). Association pattern among the yield attributes in varieties and hybrids of sunflower (Helianthus annuus L.). Madras Agric J 94:84-88.

Marinkovic R, (1992). Path coefficient analysis of some yield components of sunflower. Euphytica 60(3):201-205.

Shankar VG, Ganesh M, Ranganatha ARG, Bhave MHV, (2006). A study on correlation and path analysis of seed yield and yield components in sunflower (Helianthus annuus L.) Agric Sci Digest 26(2):87-90.

Shrinivasa MK (1982). Inheritance of fertility restoration and oil content in sunflower. M.Sc (Ag.) Thesis, University of Agricultural Sciences, Bangalore, India.

Singh RK, Chaudhary BD (1979). Biometrical methods in quantitative genetic analysis. Kalyani Publishers, New Delhi, India, $303 \mathrm{p}$.

Singh JV, Yadva TP, Kharb RPS (1985). Correlation and path coefficient analysis of sunflower. Indian J Agric Sci 95(1):243246.

Tahir MHN, Imran M, Hussain MK (2002). Evaluation of sunflower (Helianthus annuus L.) inbred lines for drought tolerance. Int j Agric Biol 4(3):398-400.

Tariq M, Idress G, Tahir A (1992). Genetic variability and correlation studies in sunflower. Sarhad J Agric 8(6):659-663.

Teklewold A, Jayaramaiah H, Jagadeesh BN (2000). Correlations and path analysis of physiomorphological characters of sunflower (Helianthus annuus L.) as related to breeding method. Helia 23(32):105-114.

Velkov VN (1980). Relation between yield and some characters in sunflower. Genetica Selektsiya 13b(5):329-338.

Vidhyavathi R, Mahalakshmi P, Manivannan N, Muralidhran N (2005). Correlation and path analysis in sunflower (Helianthus annuus L.). Agric Sci Digest 25(1):6-10. 